Original Paper

\title{
Economic Analysis on Small-Scale Forest Biomass Gasification Considering Regional Resource Distribution and Technical Characteristics
}

\author{
Kenjiro YAGI, and Toshihiko NAKATA \\ (Received March 30, 2006)
}

\author{
資源分布と技術特性を考慮した森林バイオマス小規模ガス化システムの経済性評価 \\ 八木賢治郎，中田俊彦
}

\begin{abstract}
Small-scale wood biomass gasification is considered as a suitable technology to utilize forest biomass such as logging residue and unused thinned wood. Recently, more than 10 demonstration plants have started to operate to verify both technical and economic feasibility of the system. This study analyzes the economic aspect of gasification system focusing on the regional distribution of biomass resources and technical characteristics such as scale merit.

The authors developed BiRReT tool, which conducts the economic analysis of biomass energy system in a local region by finding the optimal conditions, namely plant size, plant location, and the number of plants. Case study in Miyagi prefecture had been carried out. Firstly, the economics of gasification system is compared with the steam-turbine-based CHP system that utilizes grate or fluidized-bed combustion technology. The result shows that gasification system has strong advantage in terms of low fuel transportation cost. Secondly, the economic feasibility of the system in a region is analyzed. The system with logging residue fuel has the possibility to gain economic competitiveness if technology learning and cost reduction will be seen in the capital cost and the fuel production process. Thinned wood will not be utilized only for the energy purpose.
\end{abstract}

\section{Key Words}

Forest biomass, Wood biomass gasification, Economic analysis, Local energy system

\section{1. はじめに}

近年，建設発生木材（建築廃材）等を主燃料とする木質バ イオマス直接燃焼発電プラントの建設が進んでいる11。その背 景には，建設リサイクル法（2000 年制定）の施行や，農林水 産省，環境省，NEDO などによる，施設導入に対する各種補 助制度がある。たとえば宮城県では，石巻市の合板工場や製 紙工場にて導入されている2)。これらプラントにおける木質燃 料消費量は，合わせて年間約 20 万トンであるが2)，県内の建 設発生木材の総量は約 9 万 5 千トンと報告されている3)。つま り県内の燃料消費量は建設発生木材の県内発生量を上回って いて，東北他県や関東地方などから燃料を輸送しているのが 現状である2)。東北他県でも直接燃焼発電プラントの建設や計 画が進んでいて ${ }^{12)}$, 設備容量の増加に伴って安価な燃料の確 保が困難になりつつある。また関東地方でも，木くずの確保 が困難なために木質バイオマス発電の計画が中止となった例

Graduate School of Engineering, Tohoku University Aoba-Yama 6-6-11-815, Sendai, Miyagi 980-8579, Japan
が報告されている。

一方, 林業の振興, 適切な森林管理といった観点からも有 効利用が求められる林地残材や未利用間伐材 (以後, 森林バ イオマスと総称) は, 多くの賦存量があるが4), 利活用は進ん でいない。廃材処理という側面を持つ建設発生木材と製材残 材が安価あるいは逆有償で取引されているのに比べて，森林 バイオマスは林内の集材, トラック輸送, トラックの積込み・ 荷降ろしに費用がかさむからである。また森林バイオマスは， 資源の発生地点が森林内に点在しているため，1 个所へ大量 に収集すると輸送コストが高くなる。

直接燃焼発電は通常, 出力約千 kWe以下では, 発電効率が 著しく低下して経済性に劣る。出力千 kWe以上のプラントで は, 年間数万トン以上の燃料供給が必要となり, 広範囲から の森林バイオマス資源の収集が必要なため輸送コストが高く なる。一方, 現在多くのメーカーで実証試験が進められてい

東北大学大学院工学研究科技術社会システム専攻

$\bar{\top} 980-8579$ 宮城県仙台市青葉区荒巻字青葉 6-6-11-815 
るガス化発電は, 数 10 数 $100 \mathrm{kWe}$ 程度の小規模出力でも高 効率の発電が可能であるため, 資源の収集範囲が比較的狭く, 輸送コストを低く抑えることができる。そのため, 地域に広 く薄く分布する森林バイオマス資源をエネルギー利用する技 術として，今後の実用化および普及が期待されている。

そこで本研究では，森林バイオマスを燃料とした小規模ガ ス化発電に焦点を当てる。筆者らは, 対象地域における資源 分布と対象技術の技術特性にもとづいて, 最適なプラント規 模, 立地地点, プラント数, および最小発電コストを解析す るッール BiRReT (Biomass Economic Analysis Tool considering Regional Resource Distribution and Technical Characteristics such as Scale Merit）を，C++言語を用いて開発した。本 稿では，まず解析ッールについて説明して，次に宮城県を対 象として行ったケーススタディーの結果を報告する。ケース スタディーでは, 森林バイオマスを主燃料とするエネルギー システムを想定して，小規模ガス化技術と直接燃焼技術との 経済性を比較した。また，温泉，公共施設，福祉施設などの 業務部門を対象とする小規模ガス化熱電併給システムを想定 して, 経済性の観点から導入可能性の検討を行った。

\section{2. 資源分布と技術特性を考慮した森林バイオマス発電経済 性解析ツールの開発}

\section{1 ツールの概念設計}

本ツールは，バイオマス資源の地域分布や発電技術のス ケールメリットを考慮して, 対象地域全体におけるバイオマ ス発電の経済性を解析する。解析手順を Fig. 1 に示す。発電 プラントには，規模が大きくなると発電効率が向上して建設 単価 (JPY/kWe) も下がるというスケールメリットがある。一 方で，プラント規模が大きくなると，大量のバイオマス燃料 を広範囲から収集する必要が生じて資源輸送コストが高くな る。このトレードオフを考慮して, 発電コストが最小となる プラント規模 (Optimal plant size) を算出する。次に, プラン 卜周辺の資源分布によって輸送コストおよび発電コストが影

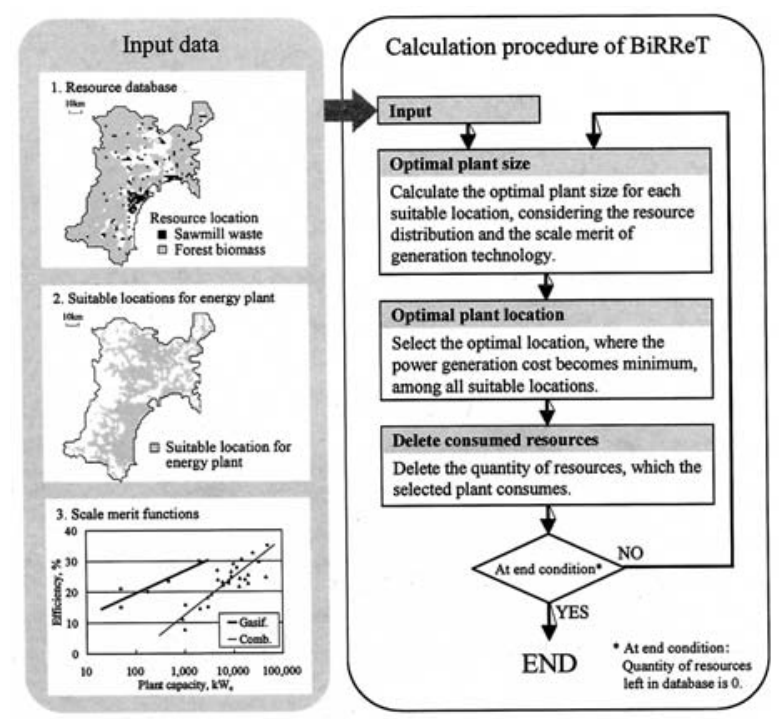

Fig. 1 Calculation procedure of BiRReT tool
響を受けるために, 発電コストが最小となるプラント立地地 点 (Optimal plant location) を 1 ケ所選択する。さらに, 選択 したプラントが消費する資源量を資源量データベース (Resource database) から除去した後，同じ計算を繰り返すこ とで，地域のバイオマス資源量をすべて有効活用する場合の プラント数を求める。解析結果として, 各プラントの最適規 模, 最適立地地点, 最小発電コストを出力する。

複数プラントの建設を同時に考慮する全体最適化ではなく， コストの低いプラントから順番に建てられていくという前提 のもとで，プラントごとの最適条件を順に求めるツールであ る。

\section{2 最適な発電プラント規模の計算}

資源量データベースは，発生地点 $\left(X_{i}, Y_{i}\right)$, 資源量 $Q_{i j}$, 資 源価格 $P_{i, j}$, 資源の低位発熱量 $L H V_{i, j}$ の 4 種類のデー夕から成 る。i，jはそれぞれ資源発生地点番号と資源の種類を示し，1 つの資源発生地点には複数の資源が存在し得るために， $Q, P$, $L H V$ は 2 次元配列となる。

ある立地候補地点 (suitable location) $k$ において, 発電コス 卜が最小となるプラント規模を求める手順を説明する。ス ケールメリット関数Effic(Cap) およびSCC (Cap) (Fig. 2(a), (b) 参照) は入力関数として与えられている。Effic (Cap) はプ ラント規模 Cap と発電効率Effic との関係を, SCC (Cap) はプ ラント規模 Cap と建設単価 SCC との関係を, それぞれ表す関

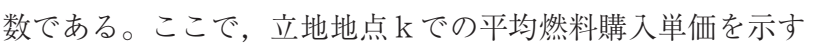
関数を $A F P_{k}(C a p)$ (Fig. 2(d) 参照) で示し, 運転維持費 $O M$ は 一定と仮定すると, 発電コストを表す関数 $G C_{k}(\mathrm{Cap})$ (Fig. 2 (e)参照) は以下の式で示される。

$$
\begin{array}{r}
G C_{k}(\mathrm{Cap})=\left(\frac{S C C(C A P)}{8760} \times C R F \times \frac{1}{A F}\right)+\frac{A F P_{k}(C A P)}{\operatorname{Effic}(C A P) / 100} \\
+O M
\end{array}
$$

$C R F$ (capital recovery factor) は一般に投資回収係数と呼ばれ, ここでは割引率とプラントの寿命とを考慮して発電コスト中 に占める建設単価分を求める係数である。AF (availability factor) はプラントの稼動率である。本研究では, 割引率を 5 \%，プラント寿命を 15 年，稼働率を $80 \%$ と設定した。

このとき, 以下の条件を満たすプラント規模Capのとき, 発 電コスト $G C_{k}$ は最小となる。

$$
\frac{d G C_{k}}{d C a p}=0
$$

この条件を求めることによって, ある立地候補地点 $k$ におけ る最適プラント規模 optCapk 抒よび最小発電コスト minG $C_{k}$ を 導出できる (Fig. 2 (e) 参照)。

式 (1) 右辺の関数の中で, 平均燃料購入単価を示す関数 $A F P_{k}(C a p)$ のが明らかになっていない。資源量データベー スの情報をもとに $A F P_{k}(C a p)$ を導出する方法について述べ る。はじめに, 各資源発生地点沙ら, 立地候補地点 $k$ までの 距離 $T D_{\mathrm{i}, \mathrm{k}}$ を求める。ただし, 直線距離に係数 $\alpha$ を乗じて道路 走行距離とする。県内のランダムな 2 点を 10 組選択して直線 および道路走行距離を計測した結果， $\alpha$ は1.2〜1.7であった。 


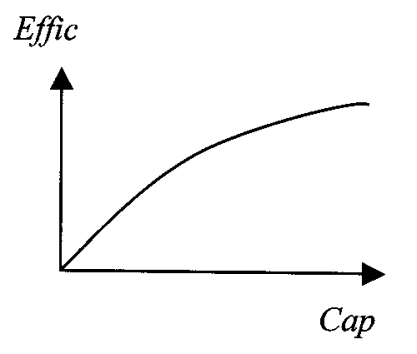

(a) Scale merit function Effic(Cap)

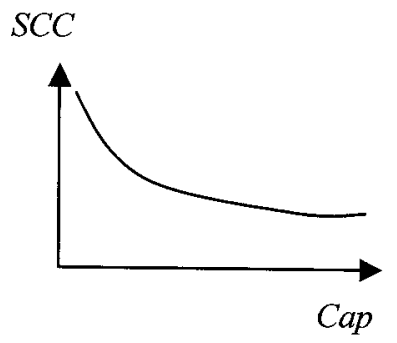

(b) Scale merit function $S C C(C a p)$

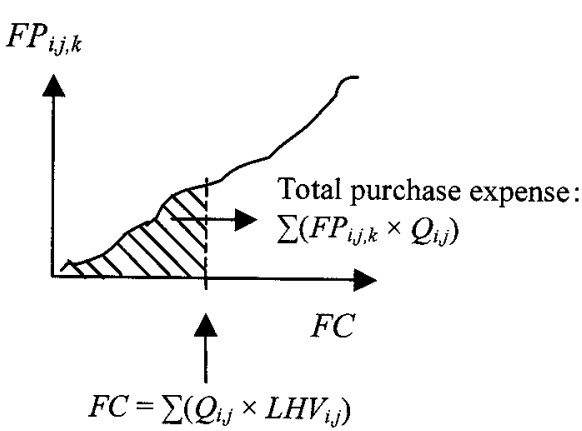

(c) Individual fuel purchase price function for each fuel
$A F P_{k}$

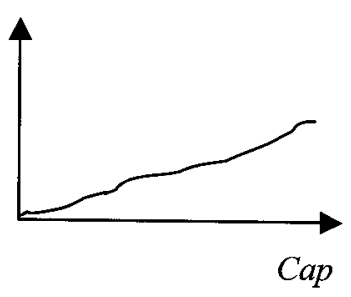

(d) Average fuel purchase price function

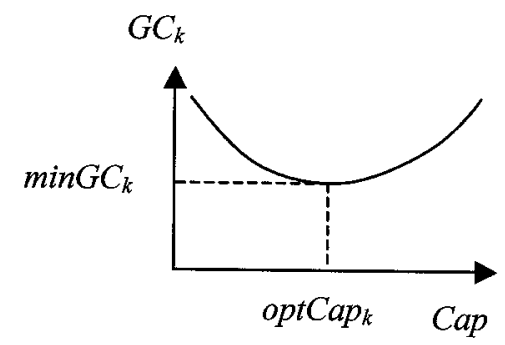

(e) Generation cost function

\section{Subscriptions: $i$ : ordering number for resource points $j$ : resource types \\ $k$ : ordering number for suitable plant locations}

Fig. 2 Conceptual figures of functions utilized to calculate optimal plant size

本研究では， $\alpha$ を 1.5 と設定した。

$$
T D_{i, k}=\alpha \times \sqrt{\left(X_{i}-X_{k}\right)^{2}+\left(Y_{i}-Y_{k}\right)^{2}}
$$

輸送コスト関数 TC $(T D)$ が入力関数として与えられているの

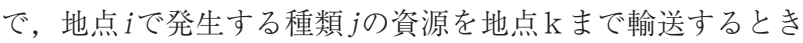
の燃料購入価格 $F P_{i, j, k}$ を計算することができる。

$$
F P_{i, j, k}=P_{i, j}+T C\left(T D_{i, k}\right)
$$

ここで, 購入価格 $F P_{i, j, k}$ の低い燃料から順番に購入していくと 考える。Fig. $2(\mathrm{c})$ は，購入価格 $F P_{i, j, k}$ の低い順番に資源を並べ て, 横軸を年間燃料消費量 $F C\left(=\Sigma\left(Q_{i j} \times L H V_{i, j}\right)\right)$ で示した 概念図である。あるプラント規模 Capにおける年間燃料消費 量 $F C$ は,

$$
\mathrm{FC}=\frac{C a p}{\operatorname{Effic}(\mathrm{Cap}) / 100} \times 8760 \times \mathrm{AF}
$$

で示され，このときの合計燃料購入価格は Fig. 2(c)に示すよ うに $\sum\left(F P_{i, j, k} \times Q_{i, j}\right)(\mathrm{JPY} / \mathrm{yr})$ となる。平均燃料購入単価 $A F P_{k}$ (Cap) は，合計燃料購入価格を年間燃料消費量で除して得られ る (Fig. 2(d) 参照)。

$$
A F P_{k}(C a p)=\frac{\sum\left(F P_{i, j, k} \times Q_{i, j}\right)}{F C}
$$

以上から, ある立地候補地点 $\mathrm{k} に お け る$ 平均燃料購入単価を 示す関数 $A F P_{k}(C a p)$ が導出されるので, (1), (2) 式から最適 プラント規模 optCapk 算出できる。

\section{3 最適な発電プラント立地地点の選択}

上記の手順で，すべての立地候補地点に対して最適プラン 卜規模を求める。ここで, 発電コストを最小とする最適規模 
はoptCapk, そのときの発電コストは $\min G C_{k}$ である（ただし， $k=0,1,2, \cdots, n)$ 。次に, すべての立地候補地点 $k=0,1,2$, $\cdots, n$ のから, $\min G C_{k}$ が最小である地点 $k^{*}$ を選択する。 $\min G C_{k}=\min _{k=0,1,2, \cdots, n}\left\{\min G C_{k}\right\}$

以上から，発電コストが最小となる最適プラント規模 optCapk*, 最適立地地点 $(X, Y)=\left(X_{k^{*}}, Y_{k^{*}}\right)$, 最小発電コス卜 $\min G C_{k^{*}}$ が求まる。

\section{3. 入力データとケース設定}

本節では，宮城県を対象にしたケーススタディーの入力 データおよびケース設定について述べる。

\section{1 宮城県の資源量データベース}

まず，宮城県面積に対して， $2 \mathrm{~km} \times 2 \mathrm{~km}$ 粗さのメッシュ を作成した。次に，バイオマス資源賦存量の調査報告書や森 林地図など各種文献5) 6) を参照して，それぞれのメッシュに おける林地残材 (Logging residue) 抒よび未利用間伐材 (Thinned wood) の資源発生量を推計した。さらに，おが屑・ カンナ屑 (Sawdust) や端材 (Cutting edge) などの未利用製 材残材も考慮して ${ }^{5)}$, 資源量データベースを作成した。Table 1に，データベースの合計值である県内年間発生量を示す。資 源の発熱量は含水率に影響されるため, 想定した含水率も示 す。

資源分布について概略を次に記す。資源発生量（wet-t/yr） を森林面積 (ha) で除して得られる值を資源発生密度 (wet-t) yr/ha）とすると, 森林バイオマスの県内平均值は 0.23 wet-t/ yr/haと推計された。林業が盛んな登米町, 元吉町, 東和町の 地域ではそれぞれ0.99，0.62，0.51 wet-t/yr/haと高い值となっ たが，その他の地域では $0.14 \sim 0.34$ と平均值に近い発生密度 である。

未利用製材残材については, 地点 $(52,58),(30,28),(23$, 12) (地点番号と宮城県地図との対応は，Fig. 5, Fig. 6を参照) にある製材所でそれぞれ1680，805，240 wet-ton/yrの発生量 があり，3 製材所のみで県内全発生量の $35 \%$ を占める。発生 量 50 〜 200 wet-ton/yr の製材所が 18 カ所あり 19\%を占めて いて，残りの $46 \%$ は発生量 50 wet-ton/yr 以下の製材所 149 ケ 所で占められている。

また, 森林, 水田地帯以外で人家や学校などの存在が確認 できる地点はプラント建設が可能であると仮定して，プラン 卜立地候補地点（suitable locations for energy plant）とした。

\section{2 スケールメリット関数}

NEDO や欧州委員会の報告書など1) 7) 10) を参照して, 日本 及び $\mathrm{EU} に お け る$ 既存のプラントデータをグラフにプロット し, 近似曲線を求めた (Fig. 3)。同じ施設規模であっても, 燃 料の特徵, プラントの立地地点, 熱利用の有無, などのさま ざまな条件によって, 発電効率や建設単価が変わると考えられ る。しかLFig. 3では, 直接燃焼発電, 小規模ガス化発電のい ずれの場合でも，全般に規模が大きくなるほど効率が上がり， 建設単価が低減するというスケールメリットが確認できた。

小規模ガス化発電の運転維持費を算出すると, 約 $3.5 \sim 22$ $\mathrm{JPY} / \mathrm{kWh}$ とプロジェクトごとに大きな幅が見られた。プラン 卜の多くは実証段階であり, 商用炉運転維持に要する費用の 実デー夕が得られていないためと考えられる。直接燃焼発電 のデータ11)も参照して, 本研究では運転維持費を $6 \mathrm{JPY} / \mathrm{kWh}$ と設定した。

\section{3 輸送コスト関数}

バイオマス資源輸送コストの算出では，林業作業で一般的

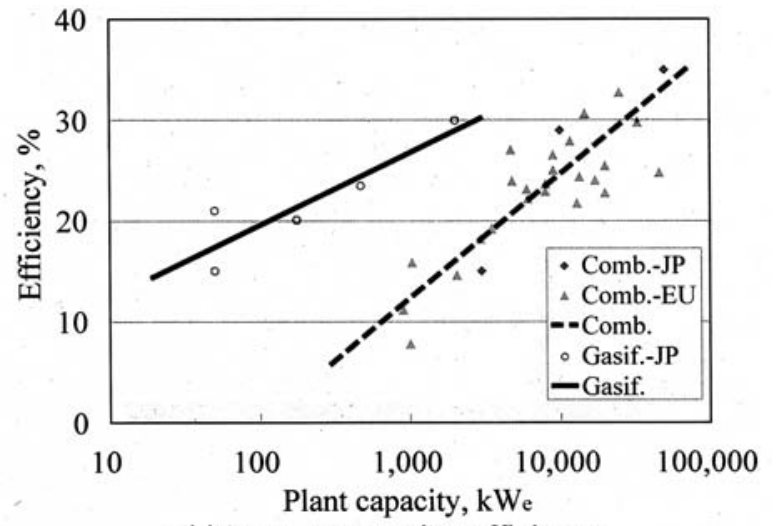

(a) Power generation efficiency

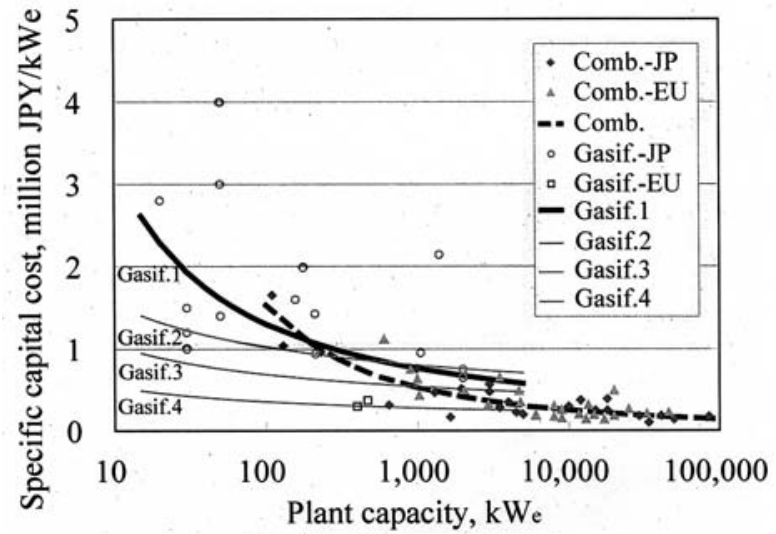

(b) Specific capital cost

Fig. 3 Scale merit functions

Table 1 The amount and moisture contents of resources

\begin{tabular}{llcc}
\hline & & $\begin{array}{c}\text { Amount 5) 6) } \\
\text { wet-t/yr }\end{array}$ & $\begin{array}{c}\text { Moisture contents } \\
\%\end{array}$ \\
\hline \multirow{2}{*}{ Sawmill waste } & Sawdust & 4,050 & 30 \\
& Cutting edge & 3,656 & 30 \\
\hline \multirow{2}{*}{ Forest biomass } & Logging residue & 47,806 & 50 \\
& Thinned wood & 48,940 & 50 \\
\hline
\end{tabular}




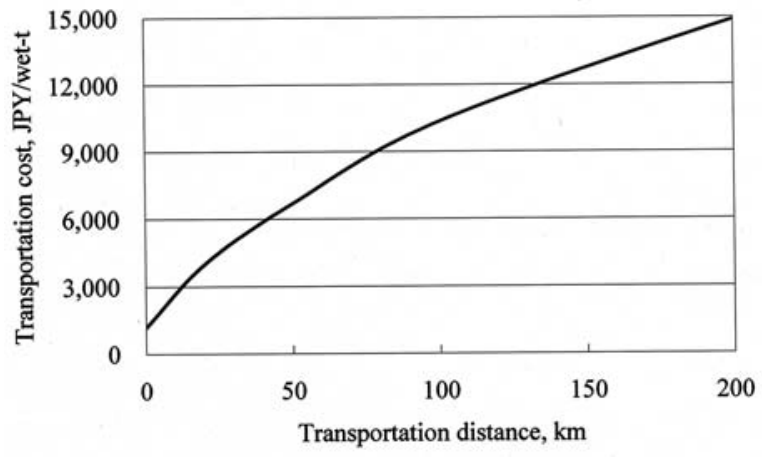

Fig. 4 Transportation cost of wood chip by 4 ton truck ${ }^{12) ~}$ 14)

に使われている4トントラックの使用を仮定した。文献 ${ }^{12)}{ }^{13)}$ では素材（丸太）輸送時のコストが示されているが，本研究 ではチップ状（またはバンドリングされた状態）を想定して いるため, 素材とチップのかさ比重の差 ${ }^{14)}$ を考慮して, 輸送 コスト関数 $T C(T D)$ を算出した（Fig. 4)。関数の設定では, トラックの積込み, 荷降ろし作業に要するコストも考慮して いる。

\section{4 ケース設定}

本研究では，プラント建設単価SCC とバイオマス資源価格 に対して，それぞれケース設定を行う。

プラント建設単価SCCに対するケース設定をTable 2 と Fig. 3(b)に示す。直接燃焼発電のSCC関数を図中のComb.で示す。
小規模ガス化発電のSCC 関数は, 現状がGasif. 1で表わされ， 建設単価が今後低減していく場合を想定してGasif. 2〜4を設 定した。

・ Comb. ケース : 既存の直接燃焼発電プラントのデータから 近似した曲線である。

・ Gasif. 1ケース：既存のガス化発電プラント（実証段階）の データから近似した曲線である。

・ Gasif. 2 ケース：ガス化技術が実用段階に入るケースであ る。既存のガス化発電プラントは実証段階であるため, データのばらつきが大きい。実証試験が終わって商用炉の 導入が始まるときには，比較的低い值に落ち着くものと想 定して，Gasif. 2 の関数を設定する。

• Gasif. 3 ケース : Gasif. 2 と Gasif. 4 との中間值である。

- Gasif. 4ケース: 北欧のプラントと同程度まで建設単価が低 減するケースである。木質バイオマスの先進地域である北 欧諸国では，建設単価が非常に安価な例が報告されている (図中の “Gasif.-EU”参照)。わが国でも，今後の技術習熟 によって同程度までの低減が可能となる場合を想定して, Gasif. 4 を設定した。

ガス化発電では，温泉，公共施設，福祉施設など業務部門 への熱電併給システム導入を想定しているため, 出力は数 $100 \mathrm{kWe}$ 以が適切と考えられる。解析では, ガス化発電の出 力上限として $300 \mathrm{kWe}$ を設けた。

次に，バイオマス資源価格のケース設定をTable 3に示す。

Table 2 Case setting for specific capital cost

\begin{tabular}{|c|c|c|c|}
\hline$\overline{\text { Case }}$ & Power generation technology & Capacity limit & SCC function \\
\hline Comb. & $\begin{array}{c}\text { Combustion (Stoker or Fluidized-bed) } \\
+ \text { steam turbine }\end{array}$ & no limitation & \multirow{5}{*}{ See Fig. 3 (b) } \\
\hline Gasif. 1 & \multirow{4}{*}{$\begin{array}{c}\text { Small-scale gasification }+ \\
\text { gas engine/gas turbine }\end{array}$} & \multirow{4}{*}{$300 \mathrm{kWe}$} & \\
\hline Gasif. 2 & & & \\
\hline Gasif. 3 & & & \\
\hline Gasif. 4 & & & \\
\hline
\end{tabular}

Table 3 Case setting for forest biomass price ${ }^{14)} \sim 17$ )

\begin{tabular}{|c|c|c|c|c|c|}
\hline \multirow[t]{2}{*}{ Case } & \multirow[t]{2}{*}{ Process } & \multicolumn{4}{|c|}{ Cost to produce forest biomass fuels, JPY/dry-t } \\
\hline & & Sawdust & Cutting edge & Logging residue & Thinned wood \\
\hline \multirow{5}{*}{ BAU } & Whole-tree yarding & & & & 9,000 \\
\hline & Chipping in a forest & & & 10,000 & 10,000 \\
\hline & Forwarder hauling & & & 4,000 & 4,000 \\
\hline & Chipping at the plant & & 3,300 & & \\
\hline & Total & 0 & 3,300 & 14,000 & 23,000 \\
\hline \multirow{4}{*}{ Low 1} & Whole-tree yarding & & & & 9,000 \\
\hline & Chipping in a forest & & & 8,000 & 8,000 \\
\hline & Chipping at the plant & & 3,300 & & \\
\hline & Total & 0 & 3,300 & 8,000 & 17,000 \\
\hline \multirow{4}{*}{ Low 2} & Whole-tree yarding & & & & 9,000 \\
\hline & Bandling & & & 3,200 & 3,200 \\
\hline & Chipping at the plant & & 1,400 & 1,400 & 1,400 \\
\hline & Total & 0 & 1,400 & 4,600 & 13,600 \\
\hline
\end{tabular}


現状の BAU（Business as usual）ケースから，新方式導入や 技術習熟によって資源価格が低減することを想定して, Low 1 ケース，Low 2 ケースを設定した。

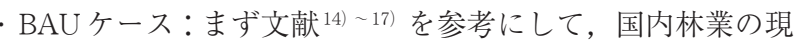
状を考慮した代表的な值をBAUケースとする。林地残材の 価格設定では，全木集材，プロセッサ造材により林内の先 山土場に発生した枝条・末木を，移動式チッパーでチップ 化して，そのチップをフォワーダで林道端土場まで運搬し， その後発電施設までトラック輸送するシステムを想定す る ${ }^{15)}$ 17)。未利用間伐材の価格設定では，高性能林業機械を 用いた列状間伐方式の作業を想定する16)。ただし，Table 1 に示す資源量は，切捨て間伐の実績値をもとに算出してい るため，チェーンソー伐木コストは含まず，集材コストの みを考慮する。集材後のチップ化コストは, 林地残材と同 様である。次に製材残材については，おが屑はそのまま工 ネルギー利用が可能な形状であるため $0 \mathrm{JPY} /$ dry-t とした。 端材はエネルギー施設でのチップ化を想定して価格設定し た ${ }^{16)}$ 。

・Low 1 ケース：フォワーダ運搬コスト分が削減されるケー スである。価格設定では，作業路の道幅が十分広く 4 トン トラックの走行も可能となる場合, または林道端でプロ セッサ造材を行う作業システムの場合を想定した。これら の場合は，フォワーダによる林道端までのチップ運搬コス 卜を削減できると考える。また移動式チッパーの作業効率 向上も考慮に入れる ${ }^{17)}$ 。

・ Low 2 ケース：新方式導入等により，さらにコストが低減 するケースである。価格設定では，ヨーロッパで導入され ているバンドリング技術が国内林業にも適用可能となる場 合 ${ }^{15)}$ ，または国内林業に適した類似技術が開発される場合 を想定した。またエネルギー変換施設でのチップ化の作業 効率向上も考慮に入れる ${ }^{15)}$ 。

以上，文献を参照して 3 ケースの価格設定を行ったが，実 際の林業作業コストは, 路網の整備状況, 地形条件, 作業シ ステムなどの作業現場ごとの条件に大きく影響される。全般 的には, 習熟曲線を用いた北欧諸国での先行研究で報告され ているように ${ }^{18)}$ ，森林バイオマス燃料の利活用が進むにつれ て，新方式導入や技術習熟によって徐々にコストが低減する と考えられる。

4. 解析結果 : 宮城県を対象としたケーススタディー

4.1 最適プラント規模, 立地地点, プラント数, および最 小発電コストの算出

ッールを用いて, 最適なプラント規模, 立地地点, プラン 卜数，および最小発電コス卜を解析した。直接燃焼発電Comb ケースの結果をFig. 5 に, 小規模ガス化発電Gasif. 1ケースの 結果を Fig. 6 に，それぞれ示す。ただし，バイオマス資源価 格はBAUケースである。Comb.ケースでは，5,500kWeおよび $1,200 \mathrm{kWe}$ という比較的大規模なプラントが選択されて，2 基 だけで宮城県内のすべての資源量を利用する結果となった。 これは, Fig. 3 に示すように，数 $100 \mathrm{kWe}$ 程度の小規模では発

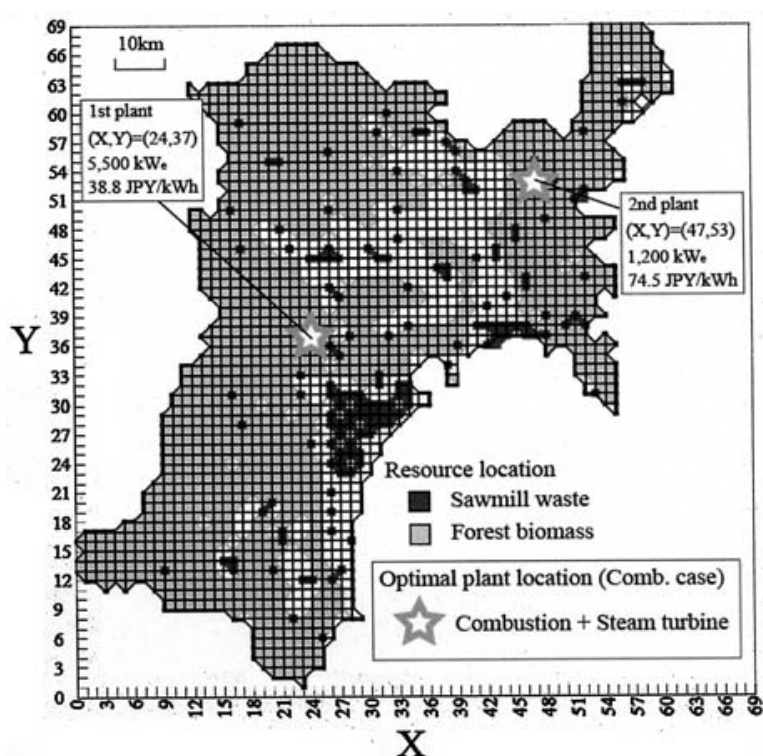

Fig. 5 Optimal plant locations (Comb. case \& BAU case)

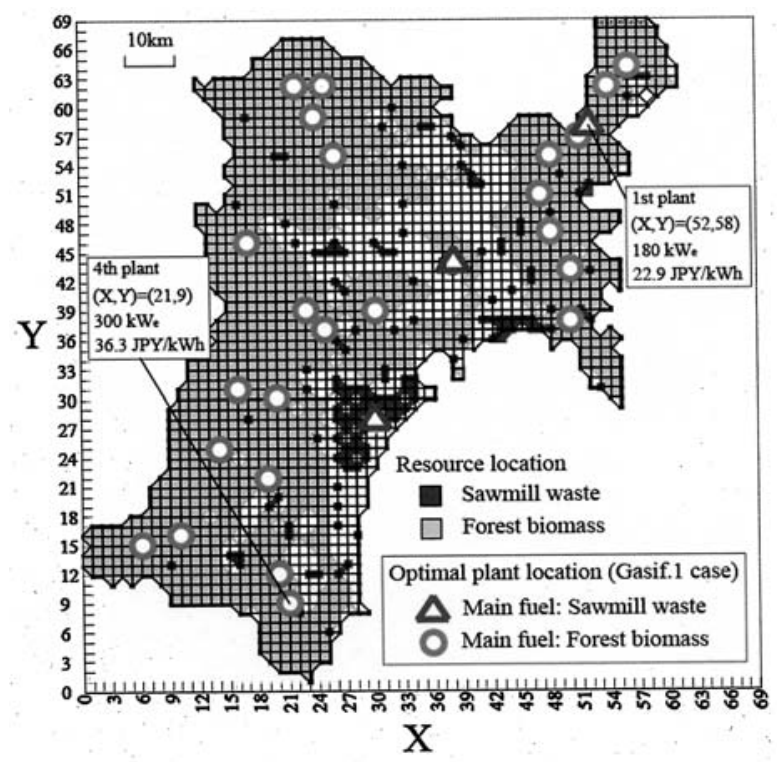

Fig. 6 Optimal plant locations (Gasif. 1 case \& BAU case)

電効率が $10 \%$ 以下と著しく低く，発電コストが高くなるから である。Gasif. 1 ケースでは, 小規模のプラント 27 基で, 県 内の資源をすべてエネルギー利用する結果となった。製材残 材を主燃料とするプラント $(\triangle)$ は, 資源発生地点である製 材所周辺に立地している。一方で，森林バイオマスを主燃料 とするプラント (○) は，周辺が森林に囲まれている山間部 に立地している。

Fig. 7 には, Fig. 6 に示す全 27 基のプラントの発電コスト とその内訳を，横軸に累積発電容量をとって示す。横軸では， 1 基目のプラントが左から始まり，27基目のプラントが右端 に示されている。資源コスト (Resource) が階段状に上がり, それに合わせて発電コスト（Total）も階段状に上昇している。 まず最も価格の安い製材残材を利用したプラントが選択され， その資源量が少なくなると, 次は林地残材が選択され始め, そ の次は未利用間伐材, と選択されていく。 


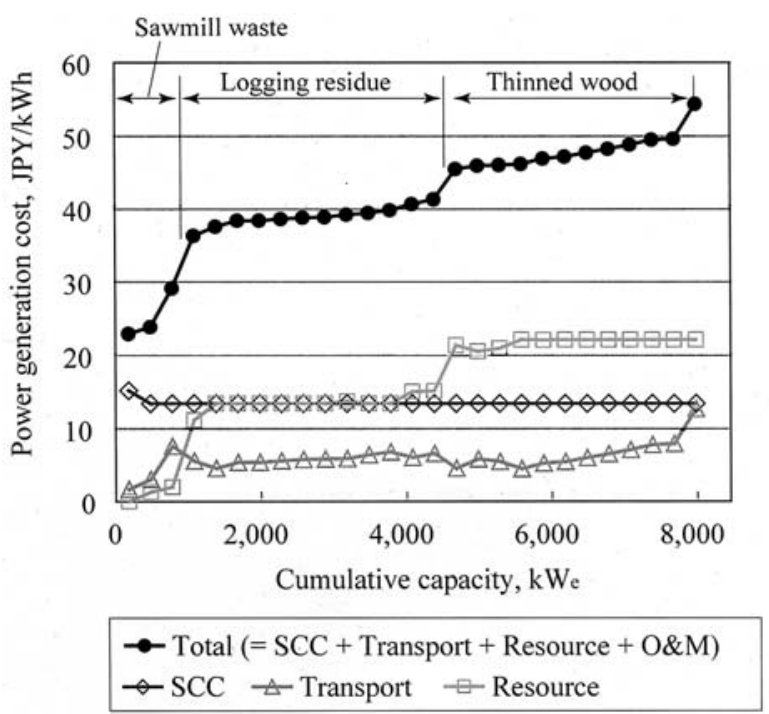

Fig. 7 Power generation cost of all 27 plants (Gasif. 1 case \& BAU case)

\section{2 小規模ガス化発電と直接燃焼発電との経済性比較}

次に，ツール解析で得られた結果をもとに，小規模ガス化 発電と直接燃焼発電との経済性比較を行う。バイオマス資源 価格は BAU ケースとする。Comb.ケース，Gasif. 1 ～Gasif. 4 ケースに打ける，全プラントの平均発電コスト(加重平均) と その内訳を Fig. 8 に示す。ここで，熱利用が可能な場合には 重油購入費削減分を発電コストの低減に反映できると想定し て，図中にマイナスで示し (図中 “Heat”)，熱によるコスト 回収も含めた総合コストも示した (図中“Net”)。ただし総合 効率を $70 \%$ と仮定して，総合効率から発電効率を減じた分を 熱利用効率とした。Comb.ケースとGasif. 1ケースでは，特に 輸送コストとプラント建設費に大きな違いがある。Comb. ケースでは発電容量が大きく建設単価が低い反面，大量の資 源を広範囲から集める必要があるために輸送コストが 15.6 $\mathrm{JPY} / \mathrm{kWh}$ と大きくなっている。一方 Gasif. 1 ケースでは，建 設単価は高いものの，小規模システムであるために輸送コス トが $6.1 \mathrm{JPY} / \mathrm{kWh}$ と低い。また，直接燃焼発電の出力は数千 kWe と大規模であり，この規模に合う熱需要は，通常合板工 場や製材工場などに限られている。一方小規模ガス化発電で は 300kWe 以下の発電容量を想定していて，温泉や福祉施設 など業務部門での熱電併給システム導入が可能と考えられる ため，熱利用が比較的容易である。そのため，図中の“Heat”

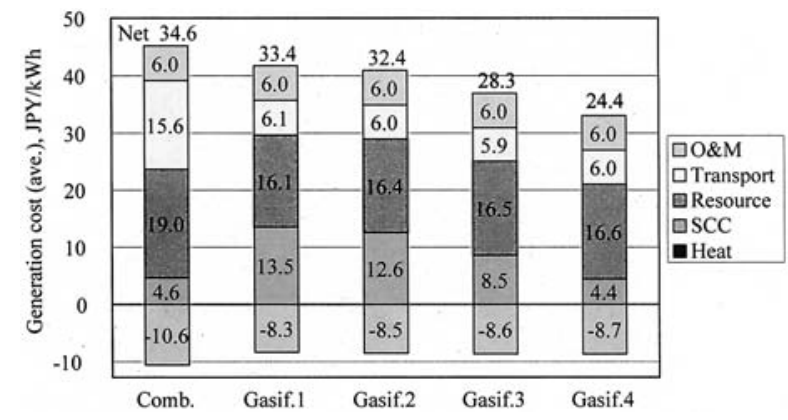

Fig. 8 The comparison of generation cost (Biomass price BAU case)
分の事業採算向上が期待できる。さらに，小規模ガス化発電 の建設単価が今後低減していく場合 (Gasif. 2 Gasif. 4 ケー ス）には，直接燃焼発電に比べて大幅に有利になる。

\section{3 小規模ガス化熱電併給システムの導入可能性}

最後に，経済性の観点から小規模ガス化熱電併給システム の導入可能性を検討する。ここでは，電力の売電単価を 4 〜 $40 \mathrm{JPY} / \mathrm{kWh}$ まで変化させて，パラメータサーベイを行った。 発電コストが売電単価よりも低ければ，プラントの事業化が 可能であると仮定して, 縦軸には事業化に伴う導入設備容量 を示した (Fig. 9)。ただし，熱利用による重油購入費削減分 を発電コストの低減に反映できるとする。Fig. 9 (a) の Gasif. 4 ケースを見ると, 売電単価が 4 〜 $20 \mathrm{JPY} / \mathrm{kWh}$ の時は製材残 材（Sawmill waste）を主燃料とするシステムしか導入されな い。売電単価が約 $20 \mathrm{JPY} / \mathrm{kWh}$ を超える場合には林地残材 (Logging residue)を主燃料とするシステムが導入され，約 28 JPY $/ \mathrm{kWh}$ を超える場合には未利用間伐材（Thinned wood）を 主燃料とするシステムが導入される。

システム導入の対象施設である温泉や公共施設における電 力購入単価を $15 \mathrm{JPY} / \mathrm{kWh}$ 前後と想定して, 図中に帯状の色 をつけて示した。この価格帯を見ると，森林バイオマス価格 BAUケースでは, Gasif. 1〜 Gasif. 4ケースのいずれの場合で も製材残材を主燃料とするシステムの導入しか見込まれない。

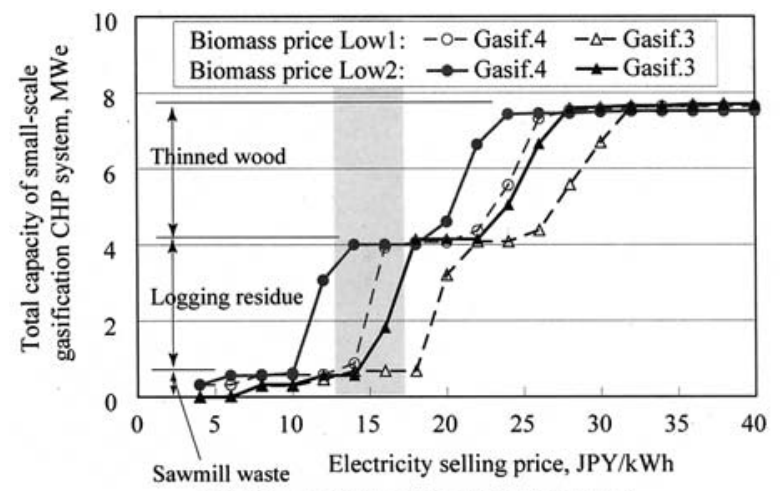

(a) Forest biomass price BAU case

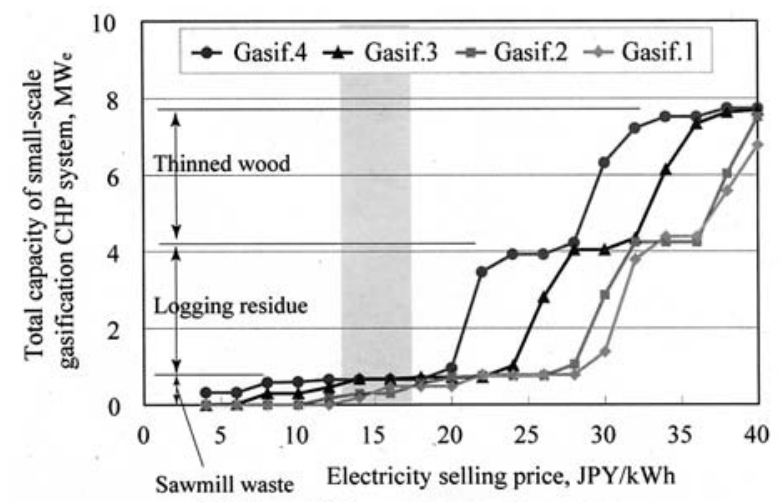

(b) Forest biomass price Low case *1 Approximate electricity selling price to a commercial sector such as hot spring and

Fig. 9 Total capacity of introduced small-scale gasification system, assuming that the system can be introduced if the generation cost is less than the electricity selling price 
次に, Low 1 ケースおよびLow 2 ケースを見ると（Fig. 9 (b) 参照)，林地残材を主燃料とするシステムの導入可能性が見込 まれる。Low 1ケースではプラント建設単価がGasif. 4ケース の場合のみだが, Low 2ケースではGasif. 3ケースまたはGasif. 4ケースの場合に導入可能性がある。そのときの導入設備容量 は約 4 MWeに達し, これが稼動した場合には, 県内の業務部 門エネルギー消費量（2000）19）の約 1.3\%に相当するエネル ギー供給が可能となる。これは, 県内の業務部門 $\mathrm{CO}_{2}$ 排出量 (2000) ${ }^{20)}$ の約 $1.3 \%$ の削減に相当する。ただ $\mathrm{CO}_{2}$ 排出量の 算出では, システム導入に伴う系統電力消費と重油消費の削 減量，およびバイオマス資源輸送に伴う排出量を考慮した。

間伐材を主燃料とするシステムは，どのケースでも導入が 見込まれない。森林バイオマスの利活用促進には, マテリア ル利用とエネルギー利用の 2 つのアプローチがある。一般的 には木材として使える部分はマテリアル利用をして，それが 不可能な残材や廃材をエネルギー利用するという, カスケー ド利用が望まれている。解析の結果, マテリアルとしての利 用可能性もある材を，コストを費やして集材しエネルギー利 用することは, 経済的な観点からも不利であることがわかっ た。森林バイオマスのエネルギー利用では, 素材生産に伴っ て発生する林地残材の利用が主流になるものと考えられる。

\section{5. 考察}

本研究では, 高性能機械化を前提とした全木集材や列状間 伐を想定して森林バイオマスを価格設定しているが，このよ うな林業システムを県内で導入しているのは 1 森林組合だけ である。森林バイオマスを主燃料とするエネルギーシステム 実現のためには，こうした林業サイドでの合理化が進むこと， また作業方法の選択にあたってエネルギー利用も想定に入れ た総合システムを構築することが必要になると考えられる。

筆者らが現地視察を行った県内の森林組合では, 高性能林 業機械が導入されていて, また路網の整備が進んでいるため にトラックが林内の土場まで走行可能な状態であった。これ はLow 1ケースに相当するため, 林地残材を主燃料とするシ ステム導入の可能性がある。つまり, 現状でも導入可能性が 見込まれる地域は存在していて, 現実的にはこれらの先進地 域からシステムの導入が進んでいくと考えられる。先進地域 で得られた知見や技術習熟が他地域へも波及することで, さ らなるシステムの導入が期待できる。

RPS 制度やグリーン電力証書システムの活用が可能な場合 には, 通常の電力販売に加えて再生可能エネルギーの環境価 值も販売できるため, 事業採算が向上する。システム導入に 対する強い価格インセンティブ付与が可能であるために, 本 研究で考慮したオンサイトエネルギー供給タイプの事業に対 するこれら制度の充実が望まれる。

実際のシステム導入に際しては, 電力や熱の需要変動を考 慮した最適システム設計を行う必要がある。蓄電, 蓄熱によ る負荷平準化システム, 系統電力や灯油・重油ボイラーによ るバックアップ, 生成ガス貯蔵による負荷追従性の向上など, 需要家の特性に応じてさまざまな可能性が考えられる。
本研究では業務部門への熱電併給システム導入を想定した が, 森林バイオマス発電には, 自然エネルギーの間欠性を補 えるという特徵がある。小規模ガス化発電を導入することで, 風力発電や太陽光発電の間欠性を補完する総合自然エネル ギーシステム ${ }^{21)}$ を設計できる。

林業分野では, 森林 GIS を用いて, 立木の資源量, 地形条 件, 路網整備状況などから資源発生量, 収穫コス卜, 収穫計 画の解析を詳細に行う先行研究 ${ }^{22}$ が報告されている。本研究 では林業作業の実績值から資源発生量を求めたが，このよう な手法を用いることで, 資源の発生量等をより詳細に扱うこ とができる。

資源分布とスケールメリットという特性は, 木質系だけで なくすべてのバイオマスに共通する。そのため, さまざまな バイオマス資源へのツールの応用が可能と考える。

\section{6. まとめ}

地域に拈ける資源分布と対象技術の技術特性を考慮して, 最適なプラント規模, 立地地点, プラント数, および最小発 電コストを解析するッールBiRReTを開発した。宮城県の森林 バイオマス資源と未利用製材残材を対象として, ツールを用 いたケーススタディーを行った。解析の結果, 以下のことが 明らかになった。

・直接燃焼技術を用いた場合は，プラント規模が大きくなっ て広範囲からの資源収集が必要であるために, 発電コスト に占める輸送コスト分が平均 $15.6 \mathrm{JPY} / \mathrm{kWh}$ と高くなる。 ・小規模ガス化発電技術は現在実証段階にあるが，森林バイ オマスの利活用技術, $\mathrm{CO}_{2}$ 排出量削減技術として, 直接燃焼 技術に比べて経済的に有利である。

・プラント建設単価または資源価格が低減する場合, 全木集 材から発生する林地残材を燃料とした小規模ガス化熱電併 給システムの発電コストは約 $15 \mathrm{JPY} / \mathrm{kWh}$ 以下となり, 温 泉，公共施設など業務部門への導入が見込まれる。

・目内の未利用製材残材と林地残材がすべて小規模ガス化シ ステムで燃料利用された場合, 合計設備容量は約 $4 \mathrm{MWe}$ なり，県内の業務部門エネルギー消費量 (2000) の約 $1.3 \%$ に相当するエネルギー供給が可能となる。このとき, 県内 の業務部門 $\mathrm{CO}_{2}$ 排出量 (2000) の約 $1.3 \%$ に相当する削減量 が得られる。

・未利用間伐材のエネルギー利用は経済的に困難であり，マ テリアル利用を中心としたカスケード的な資源利活用が重 要と考えられる。

\section{謝 辞}

宮城県産業経済部, 登米地方振興事務所, 宮城県環境生活 部, 株式会社森のエネルギー研究所からは, 研究遂行にあたっ て大変有意義なご意見，ご助言をいただきました。関係各位 へ，心より謝意を表します。

\section{文 献: References}

1) (独) 新エネルギー・産業技術総合開発機構 (NEDO), バ 
イオマスエネルギー導入ガイドブック(第 2 版), p. 51-60 (2005): New Energy and Industrial Technology Development Organization (NEDO), Guidebook for the implementation of Biomass Energy (second edition), p. 51-60 (2005)

2）(株)循環社会研究所, 平成 16 年度宮城県業務委託地域 サイクルエネルギー資源利用促進事業業務報告書，p. 9396 (2005): Institute for Reflexive Community (inReC), Report on the promotion of recycling energy in local area in Miyagi prefecture, p. 93-96 (2005)

3）東北地方建設副産物対策連絡協議会，平成 14 年度建設副 産物実態調査結果, (2004): Council of construction byproducts treatment in Tohoku region, Report on the current situation of construction by-products, (2004)

4) 三菱総合研究所，平成 14 年度新エネルギー等導入促進基 礎調査バイオマスエネルギー開発・利用戦略に関する調査 研究報告書, p. 7-9(2002): Mitsubishi Research Institute, Inc., The report on the development and strategy of biomass energy, The fundamental research on dissemination of renewable energy 2002, p. 7-9(2002)

5）エコ・アシスト, 平成 15 年度宮城県業務委託バイオマス 資源賦存量調査報告書, p. 91-116(2004)：Eco-assist Co, Ltd., Research on the available quantity of biomass resources in Miyagi prefecture, p. 91-116 (2004)

6）宮城県産業経済部森林整備課，緊急間伐 5 力年対策計画· 実績, (2005): Miyagi Prefectural Government Industry Department Forest Management Division, The plan and actual status of 5-year emergent thinning project, (2005)

7) VTT Processes, Small-scale biomass CHP technologies -situation in Finland, Denmark and Sweden, OPET Report 12, (2004)

8) TEKES, GROWING POWER -- Renewable solutions by bioenergy technology from Finland(Second edition), (2004)

9) European commission, Best practice projects yearbook 1997-2000, (2002)

10）(独)新エネルギー・産業技術総合開発機構（NEDO），バ イオマスエネルギー導入ガイドブック，p. 30-32(2003)： New Energy and Industrial Technology Development Organization (NEDO), Guidebook for the implementation of Biomass Energy, p. 30-32(2003)

11）秋田県行政資料，能代木質バイオマス発電施設の概要： Akita Prefecture, Overview of Noshiro wood biomass power station, http://www.pref.akita.jp/rinseika/info/148_6_1. htm (Access date: 2005/Jul./07)

12）日本エネルギー学会, 平成 14 年度バイオマス・ニッポン 総合戦略策定緊急調查報告書，p. 117 (2003): Japan Institute of Energy, Research followed by the establishment of Biomass Nippon Strategy, p. 117 (2003)

13）澤口勇雄，山岳林における林道路線評価と林道規格に関す
る研究 (第 1 報), (森林総研研報No. 372), p. 71, 72(1996): Sawaguchi, I., Studies on Forest-Road Evaluation and Forest-Road Standards in Mountain Forests(I), (Bulletin of Forestry and Forest Products Research Institute No. 372), p. 71, 72(1996)

14）吉岡拓如，東京大学博士論文，p. 55-60 (2003): Yoshioka, T., Doctoral thesis Tokyo University, p. 55-60 (2003)

15）吉岡拓如, 平田悟史, 松村幸彦, 坂西欣也, 日エネ誌, 81, 241-249 (2002) : Yoshioka, T., Hirata,, S., Matsumura, Y., Sakanishi, K., J. Jpn. Inst. Energy, 81, 241-249 (2002)

16）立川史郎，機械化林業，596，p. 1-4(2003): Tatsukawa, S., Kikaika Ringyo, 596, p. 1-4(2003)

17) Yoshioka, T., Aruga, K., Nitami, T., Sakai, H., Kobayashi, H., Biomass and Bioenergy, in Press

18) Junginger, M., Faaij, A., Bjorheden, R., Turkenburg, W. C., Biomass and Bioenergy, 29, 339-418 (2005)

19）宮城県，宮城県省エネルギービジョン，p. 44(2005)： Miyagi prefecture, The Vision for Energy Conservation in Miyagi, p. 44(2005)

20）宮城県，“脱・二酸化炭素”連邦みやぎ推進計画，p. 16 (2004) : Miyagi prefecture, The plan to reduce $\mathrm{CO}_{2}$ emission in Miyagi, p. 16 (2004)

21) Nakata, T., Kubo, K., Lamont, A., Energy Policy, 33, 209-219 (2005)

22）有賀一広, 吉岡拓如, 櫻井倫, 森林利用学会誌, 21 (2006), in Press : Aruga, K., Yoshioka, T., Sakurai, R., Journal of the Japan Forest Engineering Society, 21 (2006), in Press

\section{Nomenclature}

$A F \quad$ Availability factor

$A F P(C a p)$ Average fuel price(JPY/kWh)

CRF Capital recovery factor

Effic (Cap) Power generation efficiency (\%)

FC Annual fuel consumption(kWh/yr)

GC(Cap) Generation cost (JPY/kWh)

$\mathrm{FP} \quad$ Individual fuel price(JPY/wet-t)

Cap Plant capacity $(\mathrm{kWe})$

LHV Lower heating value (kWh/wet-t)

$\min G C \quad$ Minimum generation cost(JPY/kWh)

OM Operation \& maintenance cost (JPY/kWh)

optCap Optimal plant capacity (kWe)

$P \quad$ Price of resource(JPY/wet-t)

Q Quantity of resource(wet-t/yr)

SCC (Cap) Specific capital cost (JPY $/ \mathrm{kWe})$

$T C(T D) \quad$ Transport cost(JPY/wet-t)

TD Transport distance $(\mathrm{km})$

$X \quad \mathrm{X}$ coordinate in a map

$Y \quad$ Y coordinate in a map

$i \quad$ Ordering number for each mesh in a resource database 
j $\quad$ Ordering number for resource types

$k \quad$ Ordering number for each mesh in a suitable location database 